\title{
Disposition Sequence Number
}

National Cancer Institute

\section{Source}

National Cancer Institute. Disposition Sequence Number. NCI Thesaurus. Code C83249.

An identifier that describes the relative position of a disposition data within a series. 